\title{
PROPAGATION OF MATURE QUERCUS ILEX L. (HOLM OAK) TREES BY SOMATIC EMBRYOGENESIS
}

MT Martínez, MC San José, AM Vieitez, MJ Cernadas, A Ballester, E Corredoira

Group of Biotechnology and Forestry Improvement. Department of Plant Physiology. Instituto de Investigaciones Agrobiológicas de Galicia. CSIC. Avda. de Vigo s/n. 15705 Santiago de Compostela, Spain.

Plant Cell Tissue and Organ Culture (2017) 131:321-333

DOI 10.1007/s11240-017-1286-4

\begin{abstract}
Somatic embryogenesis from in vitro leaf and shoot apex explants excised from axillary shoot cultures established from two mature Quercus ilex trees has been developed. Somatic embryos (SE) were obtained from both explant types and genotypes evaluated, although embryogenic frequencies were influenced by the genotype, auxin concentration, and explant type. The explants were cultured on Murashige and Skoog salts and vitamins, supplemented with $500 \mathrm{mg} \mathrm{L}^{-1}$ casein hydrolysate $(\mathrm{CH})$ and different concentrations of indole-3-acetic acid or $\alpha$-naphthalene acetic acid (NAA) in combination with $2.22 \mu \mathrm{M}$ 6-benzylaminopurine (BA). In both genotypes, shoot apex explants were more responsive than leaf explants. The best results were obtained with apex explants of clone Q3 (11\%) cultured on medium with $21.48 \mu \mathrm{M}$ NAA plus $2.22 \mu \mathrm{M}$ BA. This combination was also effective for initiating SE from leaf explants, although the induction rates were lower (1-3\%). Embryogenic lines were maintained by repetitive embryogenesis following culture of nodular embryogenic structures on Schenk and Hildebrand medium without plant growth regulators. Low embryo multiplication rates were obtained when torpedo or early cotyledonary SE were used as initial explant for embryo proliferation, or when glutamine or $\mathrm{CH}\left(500 \mathrm{mg} \mathrm{L}^{-1}\right)$ was added to proliferation medium. For germination, cotyledonary-stage SE were isolated and stored at $4^{\circ} \mathrm{C}$ for 2 months. After cold storage, SE were cultured on germination medium consisting of Gresshoff and Doy medium, supplemented with $0.44 \mu \mathrm{M}$ BA and $20 \mu \mathrm{M}$ silver thiosulphate. Under these conditions, plantlets were regenerated from $21-66.7 \%$ of the SE generated for both genotypes.
\end{abstract}

Keywords: holm oak, IAA, leaf explant, NAA, shoot apex explant, somatic embryos.

Conflicts of interests: The authors declare that they have no conflicts of interests

*Authors for correspondence: $\underline{\text { elenac@ @iiag.csic.es } \text { and sanjose@iiag.csic.es }}$ 


\section{Introduction}

The genus Quercus is one of the most important clades of woody angiosperms in the northern hemisphere in terms of species diversity, ecological dominance and economic value (Nixon 2006). Historically, $Q$. ilex (holm oak) and $Q$. suber (cork oak) have always been present in the Iberian Peninsula, with $Q$. ilex generally being more dominant (present in $84 \%$ of the woodlands) than $Q$. suber (Gónzalez 2008). All of the Quercus-dominated forests currently existing in the Iberian Peninsula have derived from the original Mediterranean forest as a result of centuries of human use (Smit et al. 2009; Huntsinger et al. 2013). The oak woodland locally called dehesa (in Spanish) or montado (in Portuguese) constitutes an agrosilvopastoral system in which common land uses co-exist with the management of many species of economic interest. The trees in the dehesas act as ecosystem engineers, enabling grass production in poor soils under a semi-arid climate (Moreno and Pulido 2009). Oak leaves, twigs, and acorns provide a rich source of nutrients for foraging animals such as cattle, sheep, horses, and bulls. Acorns are also an important part of the diet of the Iberian pig, which yields one of the most valuable cured hams in the world, as well as other cuts of meat (Cañellas et al. 2007; Vargas et al. 2013). Production of the highly prized black truffle (Tuber melanosporum), which grows in a symbiotic relationship with holm oak roots, and highly productive big game hunting lands are another economically important aspect of the dehesas (Macaulay et al. 2013). In addition to high economic and social value, these ecosystems harbor unique and high levels of biological diversity and have therefore been identified in accordance with the EU Habitats Directive as worthy of preservation (Smit et al. 2009).

Trees are increasingly affected by insect pests and pathogens, loss of habitat, and other stresses as a result of global climate change (Merkle and Nairn 2005). High mortality and decline of holm oak trees have occurred across the southwest Iberian Peninsula as a result of lack of regeneration (Pulido et al. 2013), episodic events of drought (Corcobado et al. 2014), and a syndrome denominated "La seca" (in Spanish) or "A seca" (in Portuguese) (Pérez-Sierra et al. 2013). During the 1990s, studies by Portuguese and Spanish research groups indicated that Phytophthora cinnamomi Rands may be the main cause of this syndrome (Corcobado et al. 2013).

Biotechnological approaches, such as the use of molecular markers, genetic engineering, and the application of micropropagation can be used to produce genotypes of trees with improved tolerance or resistance to diseases (Lelu-Waler et al. 2013; Corredoira et al. 2015). Somatic embryogenesis is currently considered one of the main biotechnological techniques for mass propagation, enabling multi-varietal forestry (Park et al. 2016), and for genetic transformation, application of synthetic seed, and cryopreservation of elite genotypes (Corredoira et al. 2006a; Guan et al. 2016; Bonga 2017).

High variability in seed production in holm oak has been described, with difficulty in conserving acorns, as well as extreme recalcitrance to vegetative propagation, especially of mature trees (Mauri and Manzanera 2005; Barra-Jiménez et al. 2014). Therefore, the development of alternative methods 
of propagation such as somatic embryogenesis, are necessary. The initiation of somatic embryos (SE) from zygotic embryos of holm oak was generally less problematic than from mature material, although low induction frequencies were recorded (Mauri and Manzanera 2005). Studies on the induction of SE from mature trees include SE production from leaves (Féraud et al. 1989), catkins (Blasco et al. 2013), and teguments of developing ovules (Barra-Jiménez et al. 2014) derived from field grown trees. However, there are difficulties associated with the use of leaf and floral structure explants collected from mature trees for inducing SE, including seasonal limitations in the availability of the plant material and the control of physiological stage. The use of in vitro shoot cultures as a source of explants would enable control of growth conditions versus material collected from trees growing in the field (Corredoira et al. 2014; Ballester et al. 2016). Axillary shoot cultures produce uniform explants, an unlimited number of explants is guaranteed year round, and no sterilization of the material is required. Recently, we reported the in vitro establishment, proliferation, and rooting of holm oak shoots derived from mature trees, providing sufficient plant material for initiation of somatic embryogenesis (submitted paper).

The objective of our study was to develop a reliable procedure for inducing somatic embryogenesis from mature $Q$. ilex trees. Leaf and shoot apex explants excised from in vitro axillary shoot proliferation cultures established from mature trees were evaluated for initiating somatic embryogenesis. The capacity of different plant growth regulators (PGRs) to induce an embryogenic response, and the ability of the embryogenic lines to maintain their embryogenic competence was tested. Plantlet conversion capacity of SE was also assayed.

\section{Material and methods}

Plant material and culture conditions

In vitro axillary shoot cultures were used as the source of explants for initiating SE. Stock shoot cultures were established from nodal explants excised from forced shoots of branch segments from two 100-year-old Quercus ilex L. trees (designated Q3 and Q10). Shoot cultures were multiplied by sub-culturing axillary shoots $(1 \mathrm{~cm})$ every 6 weeks on woody plant medium (WPM; Lloyd and McCown 1980) mineral salts and vitamins (Duchefa Biochemie, Netherlands), $30 \mathrm{~g} \mathrm{~L}^{-1}$ sucrose, 20 $\mu \mathrm{M}$ silver thiosulphate (STS), and $8 \mathrm{~g} \mathrm{~L}^{-1}$ Sigma agar (A-1296; Sigma-Aldrich, St. Louis, MO, USA). Shoots were cultured vertically in WPM containing cytokinin, with a sequence of transfers every 2 weeks, as follows: $0.44 \mu \mathrm{M}$ benzyaminopurine (BA) for the first 2 weeks, $0.22 \mu \mathrm{M}$ BA for the next 2 weeks, and $0.044 \mu \mathrm{M}$ BA plus $0.46 \mu \mathrm{M}$ zeatin for the last 2 weeks in a 6-week multiplication cycle. All culture media were adjusted to $\mathrm{pH} 5.7$ before being autoclaved at $115^{\circ} \mathrm{C}$ for $20 \mathrm{~min}$. The STS was filter-sterilized and added to the autoclaved medium. Stock shoot cultures of both genotypes were maintained by periodic subculture for 1 year before being used in SE induction experiments. Stock cultures were incubated in a growth chamber with a 16-h photoperiod (provided by cool-white 
fluorescent lamps at $50-60 \mu \mathrm{mol} \mathrm{m} \mathrm{m}^{-2} \mathrm{~s}^{-1}$ ) at $25^{\circ} \mathrm{C}$ light $/ 20^{\circ} \mathrm{C}$ dark (i.e. photoperiodic culture conditions).

Induction of somatic embryogenesis

Shoot apices (2-2.5 $\mathrm{mm}$ in length, comprising the apical meristem and the corresponding leaf primordias), and the most apical expanding leaf with petiole $(4-7 \mathrm{~mm})$ from the first node in the apical region, both explants excised from shoots in an active state of growth of genotypes Q3 and Q10 were used as initial explants (Fig. 1A, B). Basal medium was composed of Murashige and Skoog (MS; 1962) mineral salts and vitamins (Duchefa Biochemie, Netherlands), $500 \mathrm{mg} \mathrm{L}^{-1}$ casein hydrolysate (CH), $6 \mathrm{~g} \mathrm{~L}^{-1}$ Vitro agar (Pronadisa, Spain) and $30 \mathrm{~g} \mathrm{~L}^{-1}$ sucrose. This basal medium was supplemented with $2.85,5.71,11.42$, and $22.83 \mu \mathrm{M}$ indole-3-acetic acid (IAA) or 5.37, 10.74, and $21.44 \mu \mathrm{M} \alpha$-naphthalene acetic acid (NAA) in combination with $2.22 \mu \mathrm{M}$ BA (induction medium M1). After 8 weeks of culture in darkness at $25^{\circ} \mathrm{C}$, the cultures were transferred to basal medium supplemented with $0.44 \mu \mathrm{M}$ BA and either $0.54 \mu \mathrm{M}$ NAA or $0.57 \mu \mathrm{M}$ IAA, for those experiments including NAA or IAA, respectively, in the induction medium (expression medium M2), and explants were cultured under the above described photoperiodic conditions for further 4 weeks. The explants were then transferred to a third medium consisting of basal medium (expression medium M3) for another 24 weeks in photoperiodic conditions (i.e. in total, for 36 weeks after the start of culture). In addition, shoot apex and leaf explants were cultured on basal medium for 36 weeks (control treatment).

Ten shoot apices (horizontally orientated) and ten leaves (abaxial side in contact with the medium) were placed in $90 \times 15 \mathrm{~mm}$ Petri dishes containing $25 \mathrm{ml}$ of induction medium. For each genotype (Q3 and Q10), 100 leaves and 100 shoot apices were cultured per auxin and control treatments.

At the end of experiments, the following data were recorded: the percentage of explants forming callus at 8 weeks and the percentage of explants showing an embryogenic response at the end of the total culture period (36 weeks). Embryogenic response was defined as the presence of nodular embryogenic structures (NS) and/or SE (torpedo-cotyledonary stage) on the initial explants and was determined by periodically examining the explants under a stereomicroscope (Olympus SZX9, Japan). Photographs were taken with an Olympus DP10 digital camera (Japan).

Maintenance of embryogenic lines

To achieve SE proliferation and maintenance of embryogenic competence, individual NS or SE, produced in induction experiments, were isolated from the original explants and subcultured into $90 \mathrm{x}$ $15 \mathrm{~mm}$ Petri dishes containing $25 \mathrm{~mL}$ of embryo proliferation medium. This medium consisted of Schenk and Hildebrand (SH; 1972) mineral salts (Duchefa Biochemie, Netherlands), MS vitamins, 30 $\mathrm{g} \mathrm{L}^{-1}$ sucrose, and $6 \mathrm{~g} \mathrm{~L}^{-1}$ Vitro agar. Various embryogenic lines were established for Q10 and Q3 
genotypes, since each line was derived from one NS or from one SE. The embryogenic lines were maintained by secondary embryogenesis, with sequential subculture at 6-week intervals, and were cultured under photoperiodic culture conditions. In preliminary experiments, the use of MS medium containing $20 \mu \mathrm{M}$ STS and 0.4\% (w/v) activated charcoal (as defined in Martínez et al. 2015) or MS medium supplemented with $0.44 \mu \mathrm{M}$ BA plus $0.27 \mu \mathrm{M}$ NAA (as defined in Martínez et al. 2008) was ineffective in maintaining the embryogenic capacity. Also, the application of alternative culture conditions, such as culturing in complete darkness, or with alternate cycles of 4 weeks in darkness/light, did not produce positive results on SE proliferation.

To improve the ability of embryogenic lines to generate secondary somatic embryos (SSE) the effect of explant type used as subcultured explant was evaluated. Three embryogenic explant types were defined: isolated nodular embryogenic structures $(0.6-1 \mathrm{~mm})$, torpedo-stage embryos $(2-2.5$ $\mathrm{mm})$, and translucent early cotyledonary-stage embryos $(3-4 \mathrm{~mm})$. These embryogenic structures were sub-cultured on SH proliferation medium. In a futher experiment, the effect of two organic nitrogen sources on the SSE capacity was tested. Isolated NS were subcultured on SH proliferation medium supplemented with $500 \mathrm{mg} \mathrm{L}^{-1}$ casein hydrolysate or $500 \mathrm{mg} \mathrm{L}^{-1}$ glutamine.

In SSE experiments, three replicate Petri dishes with eight explants per plate were cultured for each treatment, and the experiments were repeated twice. After 6 weeks of culture, the embryo proliferation ability was evaluated by recording the mean number of NS and mean number of SSE (i.e. hearttorpedo-, translucent-cotyledonary- $\leq 5 \mathrm{~mm}$ and white-opaque cotyledonary-embryos $>5 \mathrm{~mm}$ ) produced in each replicate Petri dish for each treatment.

Somatic embryo germination and plantlet conversion

Following 6-weeks of culture in SH proliferation medium, cotyledonary-stage embryos $(\geq 5 \mathrm{~mm})$ were isolated, placed in empty Petri dishes, and stored at $4^{\circ} \mathrm{C}$ for zero (control), 2 and 3 months. After cold storage treatment, the SE were transferred to $500 \mathrm{ml}$ glass jars $(11 \mathrm{x} 11 \mathrm{~cm}$; Luminarc, France $)$ containing $70 \mathrm{~mL}$ of germination medium consisting of Gresshoff and Doy medium (GD; 1972) mineral salts and vitamins (Duchefa Biochemie, Netherlands), $30 \mathrm{~g} \mathrm{~L}^{-1}$ sucrose, $6 \mathrm{~g} \mathrm{~L}^{-1}$ Vitro agar, 0.44 $\mu \mathrm{M}$ BA and $20 \mu \mathrm{M}$ STS. To compare the germination response of the 2 embryogenic lines established from Q3 y Q10 genotypes, cotyledonary-stage embryos $(\geq 5 \mathrm{~mm})$ were stratified for 2 months at $4^{\circ} \mathrm{C}$ and subsequently cultured in germination medium.

Somatic embryos were cultured in photoperiodic conditions for 8 weeks. After this period, the germination response was determined by recording the number of embryos with root only, shoot only, and the number of germinated embryos that converted into plantlets (both shoot and root development $\geq 5 \mathrm{~mm}$ ). Each treatment was evaluated in four replicate jars, each containing six mature somatic embryos (24 embryos per treatment). 


\section{Acclimatization}

After 8 weeks of culture in germination medium the plantlets were removed for acclimatization and potted in moistened garden soil (Terrahum compost, Germany) and perlite mix (1:2) in plastic pots (9 x $6.5 \mathrm{~cm}$ ). The pots were then covered with a clear plastic and placed into a phytotron at $25^{\circ} \mathrm{C}$ and $90 \%$ relative humidity under $16 \mathrm{~h}$ photoperiod $\left(95-100 \mu \mathrm{mol} \mathrm{m}^{-2} \mathrm{~s}^{-1}\right.$ provided by cool-white fluorescent lamps). After 6 weeks in these conditions, the plants were transferred to a greenhouse under conditions of natural daylight. The survival was evaluated after 3 months in the greenhouse.

\section{Histological study}

Shoot apices and leaves used as initial explants collected at day zero, and explants with visible SE and/or NS collected at different periods during the induction experiments were used for histological analysis. Samples were fixed in FAA solution (formalin, glacial acetic acid and 50\% ethanol [1:1:18 $(\mathrm{v} / \mathrm{v} / \mathrm{v})])$, dehydrated through a graded n-butanol series, and embedded in paraffin wax (Merck, Germany). Tissues were sectioned at $8 \mu \mathrm{m}$ on a Reichert-Jung rotary microtome (Leica, Heidelberg, Germany). Sections were doubled-stained with safranin-fast green (Jensen 1962) for general examination, or with periodic acid-Schiff (PAS)-naphthol blue-black to detect starch and other insoluble polysaccharides and total proteins, respectively (Feder and O'Brien 1968). The stained sections were mounted with Euckit ${ }^{\circledR}$, and images were captured with an Olympus DP71 digital camera (Japan) fitted to a Nikon-FXA microscope (Japan).

\section{Statistical analysis}

In the SE initiation experiments, the effect of explant type and PGR treatment on the callus formation frequency (Table 1,2) was analyzed statistically by two-way analysis of variance (ANOVA). The effect of explant type and PGR treatment on the SE initiation frequency (Table 1,2) was estimated using the $\chi^{2}$ test $(\mathrm{P}<0.05)$ from a contingency table. The effects of the main experimental factors on proliferation (Table 3,4) and germination (Table 5) of SE were evaluated statistically by one-way ANOVA. Test for normality and homogeneity of variance were performed prior to ANOVA. The arcsine square-root transformation was applied to proportional data prior to analysis. Non-transformed data are presented in the Tables and Figures. The least significant difference (LSD) ( $\mathrm{P} \leq 0.05)$ was used to compare means in the case of homogeneous variances, whereas Dunnett's $\mathrm{T} 3$ test $(\mathrm{P} \leq 0.05)$ was applied in the case of non-homogeneous variances. All statistical analyses were performed using SPSS for Windows (version 19.0, Chicago, USA; see SPSS for Windows 2010). 


\section{Results}

Induction of somatic embryogenesis

During the first weeks of culture on induction medium, leaf explants were swollen, enlarged, and watery in appearance. Callus development occurred mainly in the petiole zone and the leaf blade gradually turned brown and necrotic. In apex explants, the first responses observed were expansion of leaf primordia and growth followed by callus formation mainly at the cut surface. At 8 weeks following initiation, the percentage of explants forming callus was evaluated in both genotypes (Table 1, 2). In genotype $\mathrm{Q} 10$, treatment, explant type, and their interaction significantly affected this parameter ( $\mathrm{P} \leq 0.001, \mathrm{P} \leq 0.001$ and $\mathrm{P} \leq 0.05$, respectively), with highest values (90\%) in apex explants cultured on $10.74 \mu \mathrm{M}$ NAA (Table 1). In genotype Q3, the treatment also significantly influenced $(\mathrm{P} \leq 0.001)$ the callus formation, however the effect of explant type was not significant (Table 2). The interaction between explants type and treatment was significant $(\mathrm{P} \leq 0.05)$, and the highest frequency of callus formation was obtained with $10.74 \mu \mathrm{M}$ NAA and apex combination, as in genotype Q10. In medium without PGRs (control), the frequency of callus formation for both explants types and in two genotypes was significantly lower than those explants cultured on induction medium containing auxin especially for genotype Q3 (Table 1,2). After successive transfers of the explants, first to M2 medium and 4 weeks later to M3 medium, further development of callus was not observed in leaf explants, whereas in apex explants callus development increased in successive weeks of culture.

Embryogenic response was achieved in the two genotypes evaluated (Table 1, 2). In both, SE rate was significantly $(\mathrm{P} \leq 0.001)$ affected by the explants type, being a critical factor for initiating SE. In all treatments evaluated, the best results were obtained when shoot apices were used as initial explants. Although the interaction of treatment and explant type was not significant for both genotypes, the treatment significantly $(\mathrm{P} \leq 0.01)$ influenced the $\mathrm{SE}$ frequency in the case of genotype $\mathrm{Q} 3$. In both genotypes, IAA treatments were ineffective for SE initiation in leaf explants (Table 1,2). This explant type was only responsive in $21.44 \mu \mathrm{M}$ NAA plus $2.22 \mu \mathrm{M}$ BA induction medium for two genotypes and also in control treatment for Q10 genotype. In apex explants, the highest embryogenic response was obtained with induction media supplemented with the highest concentrations of auxin $(21.44 \mu \mathrm{M}$ NAA for genotype Q3 and $22.83 \mu \mathrm{M}$ IAA for genotype Q10), although an embryogenic response is observed in the majority of the treatments evaluated, including in control treatment.

The highest rate of SE was obtained in genotype Q3, in which $11 \%$ of the apex explants produced SE or NS. All induction treatments tested in apex explants of genotype Q10 generated an embryogenic response, although at a lower rate (3-8\%) than in genotype Q3.

In explants not exposed to PGRs, SE only appeared within 2-3 months of the beginning of the experiment. For initial explants treated with the induction medium containing IAA or NAA, SE were observed as early as 3 months after the start of the experiments, and the peak SE generation occurred 
between 5-6 months. Occasionally, explants with embryogenic response were observed after 8-9 months.

For leaf explants, SE generally appeared at the petiole zone, as occurred in callus development. For shoot apex explants, SE arose from callus tissue formed in the proximal region of the basal leaf primordia. The morphological appearance of SE and the creamy-translucent NS was similar for both explant types and genotypes (Fig. 1C-F). The number of NS or SE generated in the embryogenic explants was relatively low and generally one SE or NS was obtained per responsive explant (Fig. 1CF). The simultaneous presence of both NS and SE was only occasionally observed.

Maintenance of embryogenic lines

After isolation of SE and/or NS and subculture on SH medium lacking PGRs, most cultures showed a decline in the production of SSE at 2-3 months after isolation. A number of primary embryos underwent rapid differentiation to the cotyledonary-stage, even forming complete plantlets. Of all the media and conditions tested to establish and maintain the embryogenic capacity of holm oak embryogenic lines, the best results were obtained by isolating young NS or early stage SE from the original explants and subsequent subculture on SH medium without PGRs at 6 weeks of subculture intervals. It is essential to isolate embryos from the initial explant at very early stages of the embryogenic development, just before the cotyledonary stage was achieved.

Development of SE was asynchronous, and different stages of embryos were observed in the same embryo proliferation culture at the same time. Most SE showed a normal morphology, although some exhibited the typical abnormalities of the embryogenic process, such as fused cotyledons, or more than two cotyledons.

To maintain and improve the embryogenic capacity of the established lines, the effect of the explant type used for subculture was assessed. Explant type had a significant influence on embryo production in terms of newly generated NS and SSE and their developmental stage (Table 3). Although all explant types evaluated produced new NS and SSE, the sub-cultured NS were the most effective explant and produced the highest significant numbers of NS (19.3) and SSE (27.1) (Table 3). By contrast, when torpedo or early-cotyledonary SE were used, the generation of new NS (3.8 and 1.3, respectively) and the total number of SSE (10.0 and 9.9, respectively) was significantly reduced (Table 3). Thus, the most efficient procedure to maintain holm oak clonal embryogenic lines was by sub-culture of isolated NS on SH proliferation medium.

The influence of the addition of two different organic nitrogen sources (glutamine or $\mathrm{CH}$ ) to the proliferation medium was evaluated by using NS as subcultured explants (Table 4). Both glutamine and $\mathrm{CH}$ have a significant negative effect on almost all parameters evaluated, giving rise to lower numbers of NS (6.3 for glutamine and 4.0 for $\mathrm{CH}$ ) and SSE (8.2 for glutamine and 6.5 for $\mathrm{CH}$ ) than the number of NS (16.7) and SSE (27.3) obtained in proliferation medium without these compounds 
(Fig. 2A, B). No significant differences were observed between the two nitrogen sources. The mean number of cotyledonary-stage embryos in the development stage of newly generated embryos, was significantly reduced by these compounds, whereas the number of heart-torpedo embryos was not affected. It is worth noting that the values achieved by control treatment in all of the evaluated parameters (Table 4) were very similar to those obtained by subcultured NS in the experiment on the effect of explant type on SSE (Table 3), which confirmed the reproducibility of the proliferation ability of this embryogenic line.

Plantlet conversion and acclimatization

Although plantlet conversion (16.7\%) was obtained for SE that were not subjected to cold storage, the application of 2 months of cold treatment before culture in germination medium significantly $(\mathrm{P} \leq 0.01)$ improved the germination response (Table 5). Cold storage time did not significantly affect the frequencies of partial germination (only root development or only shoot development), the frequency of embryos that formed whole plantlets significantly increased $(\mathrm{P} \leq 0.01)$ when 2 months of cold storage was applied (66.7\%; Table 5). This treatment also gave rise to the most vigorous plantlets in terms of root length $(\mathrm{P} \leq 0.01)$, shoot length $(\mathrm{P} \leq 0.05)$, and leaves number ( $\mathrm{P} \leq 0.01)$ (Fig. 2C). However, plantlet conversion frequency (12.5\%) significantly decreased in SE stored in cold for 3 months, although the plantlets obtained with this treatment were similar in size to those obtained with 2 months of cold (Table 5). The germination ability of two months cold treated SE from Q3 and Q10 genotypes was compared, resulting in noticeable differences between both materials, with $21 \%$ and $50 \%$ of plantlet conversion for Q3 and Q10 genotypes, respectively.

In spite of the good quality of plantlets obtained after culture in germination medium, only a $10 \%$ of germinated embryos grew into plants and survived after 5 months in ex vitro conditions (Fig. 2D).

\section{Histological study}

As differences were observed in embryogenic capacity between leaf and apex explants, a histological study of initial explants was performed to determine their anatomical structure. Transverse sections of leaves exhibited a low level of differentiation (Fig. 3A), as expected in developing leaves. Leaves comprised a single layer of adaxial epidermis formed by polygonal vacuolated cells, each with a small nucleus. These cells were larger than the abaxial epidermal cells, which had dense cytoplasm and a centrally located nucleus. The mesophyll was formed by a double layer of palisade parenchyma on the upper side of the leaf blade and six layers of spongy parenchyma on the lower side. The latter showed no evidence of intercellular spaces or starch grains (Fig. 3B). The mid-vein consisted of vacuolated sub-epidermis and inner parenchymal cells surrounding vascular bundles. Analysis of longitudinal sections of shoot apex explants on day zero revealed that they comprised the apical meristem and four to five pairs of leaf primordia that exhibited a lower cell differentiation level than that of leaf explants, 
especially at the epidermal and mesophyll cells (Fig. 3C). Meristem bud primordia were also evident in the axil zone of each leaf primordia (Fig. 3D).

Somatic embryos and nodular embryogenic structures obtained were also analyzed at the histological level. The embryogenic character of the NS was confirmed by the presence of meristematic cells, which showed a dense protein-rich cytoplasm, small vacuoles, and a high nucleoplasmic ratio. Somatic embryos generated in initial explants exhibited a well-formed shoot and root meristem and closed vascular tissue (Fig. 1G).

\section{Discussion}

Cloning mature trees is challenging and the recalcitrance of mature material is one of the main limitations to the widespread application of SE technology for mass propagation of selected genotypes, affecting many woody angiosperm and especially conifer species (Bonga et al. 2010; Ballester et al. 2016; Bonga 2017). The findings reported here for $Q$. ilex clearly indicated that young leaf and shoot apex explants excised from axillary shoot cultures derived from mature trees were embryogenically competent, and that the SE obtained could yield plants. These results clearly improved those reported on previous attempts to induce SE from leaf explants derived from flushing branches, that were completely unsuccessful, with only non-embryogenic callus being obtained (Blasco et al. 2013; Barra-Jiménez et al. 2014). The advantages of using shoots proliferated in culture as a source of initial explants rather than explants collected directly from field-grown trees has been discussed in studies involving Quercus (San José et al. 2010; Corredoira et al. 2012; Martínez et al. 2015) and other woody species (Rugini and Caricato 1995; Corredoira et al. 2006a, 2015; Correia et al. 2011; Maillot et al. 2016). The use of floral explants to initiate the embryogenic process (BarraJiménez et al. 2014) was affected by the season, climatic conditions, and the possibility of isolating floral tissues jointly with zygotic tissues (Dr. M. Toribio, personal communication). If this occurs, the clonal fidelity of the material would be at risk, and to avoid this hypothetical situation, the use of shoot proliferation cultures to initiate SE in hardwood trees is highly recommended.

In the present study, the embryogenic response was strongly influenced by the explant type. The embryogenic capacity of apex explants was significantly higher than leaf explants. Likewise, apex explants excised from axillary shoot cultures of two genotypes of Eucalyptus globulus were also more responsive than leaf explants (Corredoira et al. 2015). The opposite was found in the other oak species already studied, in which leaves showed higher somatic embryogenesis rates than apices (San José et al. 2010; Corredoira et al. 2012; Mallón et al. 2013; Martínez et al. 2015). Holm oak leaves had a tendency to die during the initial culture period, and the calluses produced contained more necrotic tissue than those originated from leaves of other Quercus species (Corredoira et al. 2014). This low embryogenic response of expanded holm oak leaves could be related to a higher level of differentiation than that observed in leaves for other oak studies, as we determined from the histological study of various oak species (Corredoira et al. 2006b, 2012). Thus, in white oak, a 
comparative histological leaf study showed that the leaves with higher embryogenic capacity (from the most proximal leaf to the apex) have cells in an undifferentiated condition, as well as the presence of precursor guard cells stomata and low starch grains content in the mesophyll (Corredoira et al. 2012, 2014). By contrast, the histological analysis of holm oak shoot apex showed that leaf primordia attached to the axillary bud of apex explants had lower differentiation with a higher number of meristematic cells than expanded leaf explants. This fact, together with the presence of active axillary shoot meristem, could be a possible explanation for the greater embryogenic response of apex explants. Our results were consistent with those reported by Klimaszewska et al. (2011), who observed in the induction of SE from needle primordia of shoot explants from mature white spruce trees, that the origin of SE was closely related to the formation of nodules or calluses produced at the base of elongated needle primordia. Maillot et al (2016) also reported that axillary meristems were involved in callus formation and induction of embryogenesis on node explants of wine grapes.

The addition of high auxin concentration $(21.44 \mu \mathrm{M}$ NAA or $22.83 \mu \mathrm{M}$ IAA) to the induction medium improved the holm oak embryogenic response compared to the induction medium without PGRs or with lower auxin concentrations for both genotypes and explants types. Auxins are considered as the main signals for the induction of SE (Jiménez 2005; Fehér 2008). Auxins may play a dual role during induction, one related to signaling and the other to a stress component that also changes the endogenous content of auxins. The ability of mature somatic cells to induce the embryogenic response generally depends on its capacity to switch to the meristematic or embryogenic stage, in which major de-differentiation induced by auxins has a key role. In other oak species (Vieitez et al. 2012; Corredoira et al. 2014) and other woody species, such as chestnut (Corredoira et al. 2006a) or eucalyptus species (Corredoira et al. 2015), NAA was successfully used on somatic embryogenesis initiation. As in the present report, $21.44 \mu \mathrm{M}$ NAA was also the most effective concentration for SE induction from leaf and apex explants derived from oak pedunculate seedlings (Cuenca et al. 1999) or from mature trees of several oak species (Toribio et al. 2004; San José et al. 2010; Corredoira et al. 2012; Mallón 2013; Martínez et al. 2015). In cork oak leaves derived from mature trees, an increase in the NAA concentration from 10 to $50 \mu \mathrm{M}$ enhanced the SE induction rate (Hernández et al. 2003a, b). For genotype Q10, the best results were observed with $22.83 \mu \mathrm{M}$ IIA, although similar SE frequencies were obtained for the rest of the NAA and IAA concentrations. To our knowledge, this is the first study in which IAA was successfully used for SE induction in Quercus species. These results show an auxin specificity for SE initiation, and holm oak genotypes behave differently under the same conditions. Therefore, the role of genotype should be interpreted carefully, and culture conditions should be optimized (Correia et al. 2011; Corredoira et al. 2015).

The same three-step procedure with a sequence of culture on M1 induction medium and M2 and M3 expression medium applied in the present report has been also used on induction of SE in other oak species (Corredoira et al. 2014; Martínez et al. 2015). In all these reports, SE generally was evident after transfer to M3 medium in which explants were cultured between 2-3 months. In holm 
oak, the formation of SE or NS seems to occur in two successive 'waves': one early and another late after 3-4 months in M3 medium, and in which most of the SE is formed. This fact indicates that the process of SE formation in holm oak requires more time in M3 medium.

In the present study, acceptable and higher induction rates were obtained from apex explants relative to those reported for other holm oak embryogenic systems. Somatic embryogenesis induction rates of 1.2-3.2\% have been reported for ovule teguments (Barra-Jiménez et al. 2014), 3\% for leaves (Féraud et al. 1989), 3.3\% for male catkins (Blasco et al. 2014), and 4.3\% for zygotic embryos (Mauri and Manzanera 2005).

Maintenance of embryogenic competence in holm oak proved to be problematic, and low embryo proliferation rates were a reported problem (Blasco et al. 2013; Barra-Jiménez et al. 2014). These authors reported that some embryogenic lines could only be maintained for 1 year, because most of the initial embryogenic lines lost their embryogenic competence, in spite of different culture conditions and/or the media tested to solve this problem. In the present study, only one SE or one NS was generated from each initial explant. This fact has been a handicap to the establishment of different embryogenic lines, most of which were lost after a few sub-cultures. The addition of PGRs to the embryo proliferation medium also did not improve the proliferation rate, as occurred in chestnut (Corredoira et al. 2003a), elm (Corredoira et al. 2003b), and in other oak species (Cuenca et al. 1999; Martínez et al. 2008; Corredoira et al. 2012; Mallón et al. 2013). The selection of the most appropriate type of explant was essential to maintain the embryogenic competence. The use of individual NS as sub-cultured explants for SSEs proliferation was the solution to keep the cultures alive for an unlimited period of time. Selection of appropriate explants was also found to be a critical step for embryo proliferation in American oak (Martínez et al. 2015), as it was found that embryogenic cultures were only maintained when NS were used as explants.

The source of organic nitrogen was recognized as an important factor in embryogenic induction and embryo histodifferentiation in somatic embryogenic systems (Merkle et al. 1995). The addition of glutamine was confirmed to be beneficial for proliferation of somatic embryos in Cryptomeria japonica (Ogita et al. 2001). Glutamine also improved the regeneration of plants from somatic embryos of European chestnut (Corredoira et al. 2008). In Abies fraseri, the addition of casein hydrolysate in combination with glutamine to the culture medium yielded high proliferation rates (Kim et al. 2008). Casein hydrolysate (at a concentration of $500 \mathrm{mg} \mathrm{L}^{-1}$ ) is also routinely added to the proliferation medium used for somatic embryos derived from pedunculate oak (Martínez et al. 2008; Corredoira et al. 2014). However, in holm oak both compounds had a negative effect on the proliferation of secondary embryos.

In the present study, acceptable conversion rates (21\% for Q3 and $50-66.7 \%$ for Q10) were obtained by application of 2 months cold treatment. This treatment was generally associated with a decrease in endogenous abscisic acid, and an increase in endogenous levels of gibberellic acid, both of which were involved in the germination process (Jimenez 2005; Corredoira et al. 2014). Two months 
of cold storage has also been used to promote maturation and germination of SE in European chestnut (Corredoira et al. 2008), cork oak (Toribio et al. 2005), and northern red oak (Vengadesan and Pijut 2009). By contrast, in American chestnut, the best results were achieved when SE were subjected to 3 months of cold treatment (Andrade and Merkle 2005). To increase the number of plants, germinated SE with only shoot development could be source of explants to initiate organogenic shoot proliferation cultures, which then could be multiplied and rooted.

Acclimatization of plantlets from SE origin was very problematic, and most of the plantlets died after a few days in a phytotron. Similarly, Barra-Jiménez et al. (2014) were also unsuccessful in keeping plants alive using conventional acclimatization procedures. The slow and episodic-type of growth of this species together with the difficult seed germination and seedling establishment (Smit et al. 2009) could be the cause of poor somatic plantlet survival. Alternative solutions need to be tested to increase the holm oak plantlet production. Factors such as environmental conditions (light intensity or humidity levels) during the acclimatization, nutrient management, and subtract combinations should be optimized to reduce holm oak plant loss.

In spite of the difficulties encountered in the embryogenic process of holm oak, a repetitive procedure has been designed for this recalcitrant oak species. Successful clonal propagation of mature endangered holm oak trees was feasible through the use of expanding leaves or apex explants collected from shoot cultures as initial explants. Once the embryogenic process was started, the selection of the most suitable subcultured explants to maintain the embryogenic competence was of prime importance to define the procedure.

\section{Funding}

This research was partially funded by Ministerio de Economía y Competitividad (MINECO, Spain), through the projects AGL2013-47400-C4-3-R and AGL2016-76143-C4-4-R.

\section{Acknowledgements}

We thank Dr. Mariano Toribio for kindly providing the plant material used to establish genotypes Q3 and Q10 in vitro. The authors also thank JC Suárez and R Montenegro for their excellent technical assistance.

\section{References}

Andrade GM, Merkle SA (2005) Enhancement of American chestnut somatic seedling production. Plant Cell Rep 24:326-334

Ballester A, Corredoira E, Vieitez AM (2016) Limitations of somatic embryogenesis in hardwood trees. In: Park Y-S, Bonga JM, Moon H-K (eds) Vegetative propagation of forest trees. National Institute of Forest Science (Nifos), Seoul, Korea, pp 56-74 
Barra-Jiménez A, Blasco M, Ruiz-Galea M, Celestino C, Alegre J, Arrillaga I, Toribio M (2014) Cloning mature holm oak trees by somatic embryogenesis. Trees 28:657-667

Blasco M, Barra A, Brisa C, Corredoira E, Segura J, Toribio M, Arrillaga I (2013) Somatic embryogenesis in holm oak male catkins. Plant Growth Regul 71:261-270

Bonga JM (2017) Can explant choice help resolve recalcitrance problems in in vitro propagation, a problem still acute especially for adult conifers? Trees 31:781-789

Bonga JM, Klimaszewska KK, von Aderkas P (2010) Recalcitrance in clonal propagation, in particular of conifers. Plant Cell Tiss Organ Cult 100:241-254

Cañellas I, Roig S, Poblaciones MJ, Gea-Izquierdo G, Olea L (2007) An approach to acorn production in Iberian dehesas. Agrofor Syst 70:3-9

Corcobado T, Cubera E, Moreno G, Solla A (2013) Quercus ilex forests are influenced by annual variations in water table, soil water deficit and fine root loss caused by Phytophthora cinnamomi. Agr For Meteorol 169:92-99

Corcobado T, Cubera E, Juárez E, Moreno G, Solla A (2014) Drought events determine performance of Quercus ilex seedlings and increase their susceptibility to Phytophthora cinnamomi. Agric For Meteorol 192-193:1-8

Corredoira E, Ballester A, Vieitez AM (2003a) Proliferation, maturation and germination of Castanea sativa Mill. somatic embryos originated from leaf explants. Ann Bot 92:129-13

Corredoira E, Ballester A, Vieitez FJ, Vieitez AM (2006a) Somatic embryogenesis in chestnut. In: Mujib A, Samaj J (eds) Plant cell monographs. Vol 2. Somatic embryogenesis. Springer-Verlag, Berlin, Heidelberg, pp 177-199

Corredoira E, Ballester A, Ibarra M, Vieitez AM (2015) Induction of somatic embryogenesis in leaf and shoot apex explants of shoot cultures derived from adult Eucalyptus globulus and Eucalyptus saligna $\mathrm{x}$ E. maidenii trees. Tree Physiol 35:663-677

Corredoira E, San-José MC, Vieitez AM (2012) Induction of somatic embryogenesis from different explants of shoot cultures derived from young Quercus alba trees. Trees 26:881-891

Corredoira E, Toribio M, Vieitez E (2014) Clonal propagation via somatic embryogenesis in Quercus spp. In: Ramawhat KG, Mérillon JM, Ahuja MR (eds) Tree biotechnology. CRC Press, Boca Raton, USA, pp 262-302

Corredoira E, Valladares S, Vieitez AM (2006b) Morphohistological analysis of the origin and development of somatic embryos from leaves of mature Quercus robur. In Vitro Cell Dev Biol Plant 42:525-533

Corredoira E, Valladares S, Vieitez AM, Ballester A (2008) Improved germination of somatic embryos and plant recovery of European chestnut. In Vitro Cell Dev Biol-Plant 44:307-315

Corredoira E, Vieitez AM, Ballester A (2003b) Proliferation and maintenance of embryogenic capacity in elm embryogenic cultures. In Vitro Cell Dev Biol Plant 39:394-401 
Correia S, Lopes ML, Canhoto JM (2011) Somatic embryogenesis induction system for cloning an adult Cyphomandra betacea (Cav.) Sendt. (tamarillo). Trees 25:1009-1020

Cuenca B, San José MC, Martínez MT, Ballester A, Vieitez AM (1999) Somatic embryogenesis from stem and leaf explants of Quercus robur. Plant Cell Rep 18:538-543

Feder N, O’Brien TP (1968) Plant microtechnique: some principles and new methods. Am J Bot $55: 123-147$

Fehér A (2008) The initiation phase of somatic embryogenesis: what we know and what we don't. Acta Biologia Szegediensis 52:53-56

Féraud-Keller C, El Maâtaoui M, Gouin O, Espagnac H (1989) Embryogenèse somatique chez trois espèces de chênes méditerranéens. Ann Sci For 46 (Suppl):130-132

Gónzalez C (2008) Analysis of the oak decline in Spain; la seca. Swedish University of Agricultural Sciences SLU, Uppsala

Gresshoff PM, Doy CH (1972) Development and differentiation of haploid Lycopersicon esculentum. Planta 107:161-170

Guan Y, Li S-G, Fan X-F, Su Z-H (2016) Application of somatic embryogenesis in woody plants. Front Plant Sci 7:1-12

Hernández I, Celestino C, Toribio M (2003a) Vegetative propagation of Quercus suber L. by somatic embryogenesis: I. Factors affecting the induction in leaves from mature cork oak trees. Plant Cell Rep 21:759-764

Hernández I, Celestino C, Alegre J, Toribio M (2003b) Vegetative propagation of Quercus suber L. by somatic embryogenesis. II. Plant regeneration from selected cork oak trees. Plant Cell Rep 21:765770

Huntsinger L, Campos P, Starrs PF, Oviedo JL, Díaz M, Standiford RB, Montero G (2013) Working landscapes of the spanish dehesa and the California oak woodlands: an introduction. In: Campos P, Huntsinger L, Oviedo JL, Starrs PF, Díaz M, Standiford RB, Montero G (eds) Mediterranean oak woodland working landscapes. Springer, Dordrecht, pp 3-23

Jensen WA (1962) Botanical histochemistry. San Francisco: WH Freeman and Co

Jiménez VM (2005) Involvement of plant hormones and plant growth regulators on in vitro somatic embryogenesis. Plant Growth Regul 47:91-110

Kim YW, Newton R, Frampton J, Han K-H (2008) Embryogenic tissue initiation and somatic embryogenesis in Fraser fir (Abies fraseir (Pursh) Poir.). In Vitro Cell Dev Biol-Plant 45:400-406

Klimaszewska K, Overton C, Stewart D, Rutledge RG (2011) Initiation of somatic embryos and regeneration of plants from primordial shoots of 10-year-old somatic white spruce and expression profiles of 11 genes followed during the tissue culture process. Planta 233:635-647

Lelu-Walter M-A, Thompson D, Harvengt L, Sanchez L, ToribioM, Pâques LE (2013) Somatic embryogenesis in forestry with a focus on Europe: state-of-the-art, benefits, challenges and future direction. Tree Genet Genomes 9:883-899 
Lloyd GB, McCown BH (1980) Commercially feasible micropropagation of mountain laurel (Kalmia latifolia) by use of shoot tip culture. Proc Int Plant Propagators Soc 30:421-437

Macaulay LT, Starrs PF, Carranza J (2013) Hunting in managed oak woodlands: contrasts among similarities. In: Campos P, Huntsinger L, Oviedo JL, Starrs PF, Díaz M, Standiford RB, Montero G (eds) Mediterranean oak woodland working landscapes. Springer, Dordrecht, pp 311-352

Maillot P, Deglène-Benbrahim L, Walter B (2016) Efficient somatic embryogenesis from meristematic explants in grapevine (Vitis vinifera L.) cv. Chardonnay: an improved protocol. Trees 30:1377-1387

Mallón R, Martínez MT, Corredoira E, Vieitez AM (2013) The positive effect of arabinogalactan on induction of somatic embryogenesis in Quercus bicolor followed by embryo maturation and plant regeneration. Trees 27:1285-1296

Martínez MT, Corredoira E, Valladares S, Jorquera L, Vieitez AM (2008) Germination and conversion of somatic embryos derived from mature Quercus robur trees: the effects of cold storage and thidiazuron. Plant Cell Tissue Organ Cult 95:341-351

Martínez MT, Vieitez AM, Corredoira E (2015) Improved secondary embryo production in Quercus alba and $Q$. rubra by activated charcoal, silver thiosuphate and sucrose. Influence developmental stage of the explant for subculture. Plant Cell Tissue Organ Cult 121:531-546

Mauri PV, Manzanera JA (2005) Protocol of somatic embryogenesis: holm oak (Quercus ilex L.). In: Jain SM, Gupta PK (eds) Protocol for somatic embryogenesis in woody plants. Springer, Dordrecht, pp 469-482

Merkle SA, Nairn CJ (2005) Hardwood tree biotechnology. In Vitro Cell Dev Biol Plant 41:602-619

Merkle SA, Parrott WA, Flinn BS (1995) Morphogenic aspects of somatic embryogenesis. In: Thorpe TA (ed) In vitro embryogenesis in plants. Kluwer Academic Publishers, Dordrecht, pp 155-203

Moreno G, Pulido F (2009) The functioning, management, and persistence of dehesas. In: RigueiroRodríguez A, McAdam, J, Mosquera-Losada MR (eds) Agroforestry in Europe. Advances in agroforestry. Springer, Netherlands, pp 127-160

Murashige T, Skoog F (1962) A revised medium for rapid growth and bioassays with tobacco tissue cultures. Physiol Plant 15:473-497

Nixon KC (2006) Global and neotropical distribution and diversity of oak (genus Quercus) and oak forests. In: Kappelle M (ed) Ecological Studies. Vol 185. Ecology and conservation of neotropical montane oak forests. Springer-Verlag, Berlin Heidelberg, pp 3-13

Ogita S, Sasamoto H, Yeung EC, Thorpe TA (2001) The effects of glutamine of the maintenance of embryogenic cultures of Cryptomeria japonica. In Vitro Cell Dev Biol-Plant 37:268-273

Park YS, Beaulieu J, Bousquet J (2016) Multi-varietal forestry integrating genomic selection and somatic embryogenesis. In: Park Y-S, Bonga JM, Moon H-K (eds) Vegetative propagation of forest trees. National Institute of Forest Science (Nifos), Seoul, Korea, pp 302-322 
Pérez-Sierra A, López-García C, León M, García-Jiménez J, Abad-Campos P, Jung T (2013) Previously nrecorded low-temperature Phytophthora species associated with Quercus decline in a mediterranean forest in eastern Spain. For Pathol 43:331-339

Pulido F, McCreary D, Cañellas I et al (2013) Oak regeneration: ecological dynamics and restoration techniques. In: Campos P, Huntsinger L, Oviedo JL, Starrs PF, Díaz M, Standiford RB, Montero G (eds) Mediterranean oak woodland working landscapes. Springer, Dordrecht, pp 123-144

Rugini E, Caricato G (1995) Somatic embryogenesis and plant recovery from mature tissues of olive cultivars (Olea europea L.) ‘Canino' and 'Moraiolo'. Plant Cell Rep 14:257-260

San José MC, Corredoira E, Martínez MT, Vidal N, Valladares S, Mallón R, Vieitez AM (2010) Shoot apex explants for induction of somatic embryogenesis in mature Quercus robur L. trees. Plant Cell Rep 29:661-671

Schenk RU, Hildebrandt AC (1972) Medium and techniques for induction of growth of monocotyledonous and dicotyledonous plant cell culture. Can J Bot 50:199-204

Smit Ch, Díaz M, Jansen P (2009) Establishment limitation of holm oak (Quercus ilex subsp. ballota (Desf.) Samp.) in a Mediterranean savanna-forest ecosystem. Ann For Sci 66:511

SPSS for Windows (2010) Guía Breve de IBM SPSS Statistics 19. SPSS Inc., IBM Company, Chicago, IL, USA, pp 171

Toribio M, Fernández C, Celestino C, Martínez MT, San-José MC, Vieitez AM (2004) Somatic embryogenesis in mature Quercus robur trees. Plant Cell Tissue Organ Cult 76:283-287

Toribio M, Celestino C, Molinas M (2005) Cork oak, Quercus suber L. In: Jain SM, Gupta PK (eds) Protocol for somatic embryogenesis in woody plants. Springer, The Netherlands, pp 445-457

Vargas JD, Huntsinger L, Starrs PF (2013) Raising livestock in oak woodlands. In: Campos P, Huntsinger L, Oviedo JL, Starrs PF, Díaz M, Standiford RB, Montero G (eds) Mediterranean oak woodland working landscapes. Springer, Dordrecht, pp 273-310

Vengadesan G, Pijut PM (2009) Somatic embryogenesis and plant regeneration of northern red oak (Quercus rubra L.). Plant Cell Tissue Organ Cult 97:141-149

Vieitez AM, Corredoira E, Martínez MT, San José MC, Sánchez C, Valladares S, Vidal N, Ballester A (2012) Application of biotechnological tools to Quercus improvement. Eur J Forest Res 131:519- 

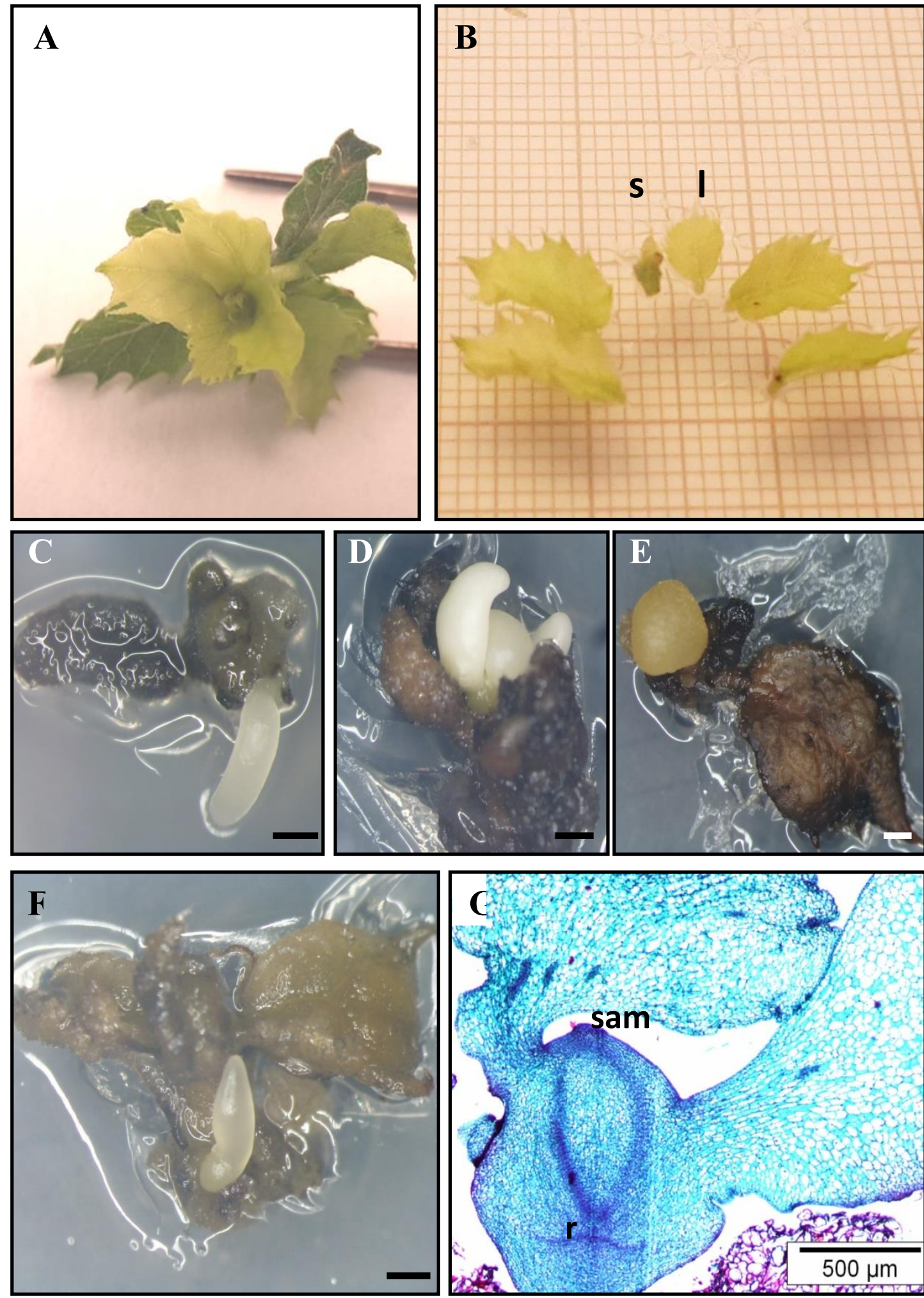

Figure 1. Induction of somatic embryogenesis in leaf and shoot apex explants excised from axillary shoot cultures established from mature holm oak trees. A Shoot proliferation cultures used as source of initial explants. B Shoot apex (sa) and expanded leaf at position 1(1) used as initial explants. C, D Somatic embryos initiated in leaf (C) and shoot apex explants (D) of genotype Q10. E, F Somatic embryos initiated in leaf (E) and shoot apex explants (F) of genotype Q3. G Histological section of the same explant as in D, showing a cotyledonary stage somatic embryo with developing root (rm) and shoot apical meristems (sam). Scale bar: $1 \mathrm{~mm}$. 

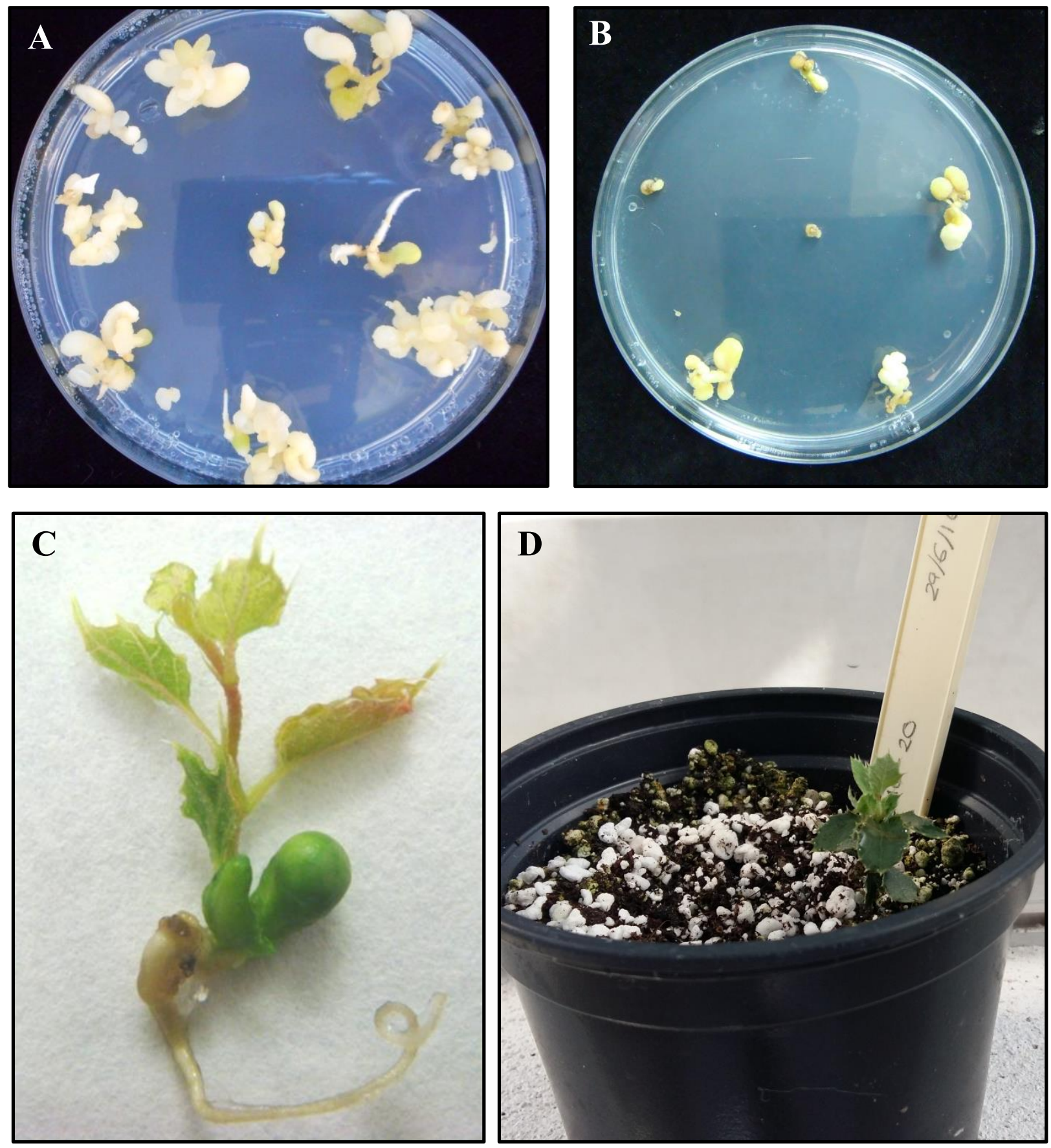

Figure 2. Maintenance of embryogenic capacity and plant regeneration of holm oak somatic embryos. A, B Secondary embryos produced from nodular embryogenic structures on proliferation medium with (A) and without (B) glutamine. C Plant regeneration from a somatic embryo after 6 weeks of culture in germination medium. D Holm oak plantlet after 1 year growing in ex vitro conditions. 

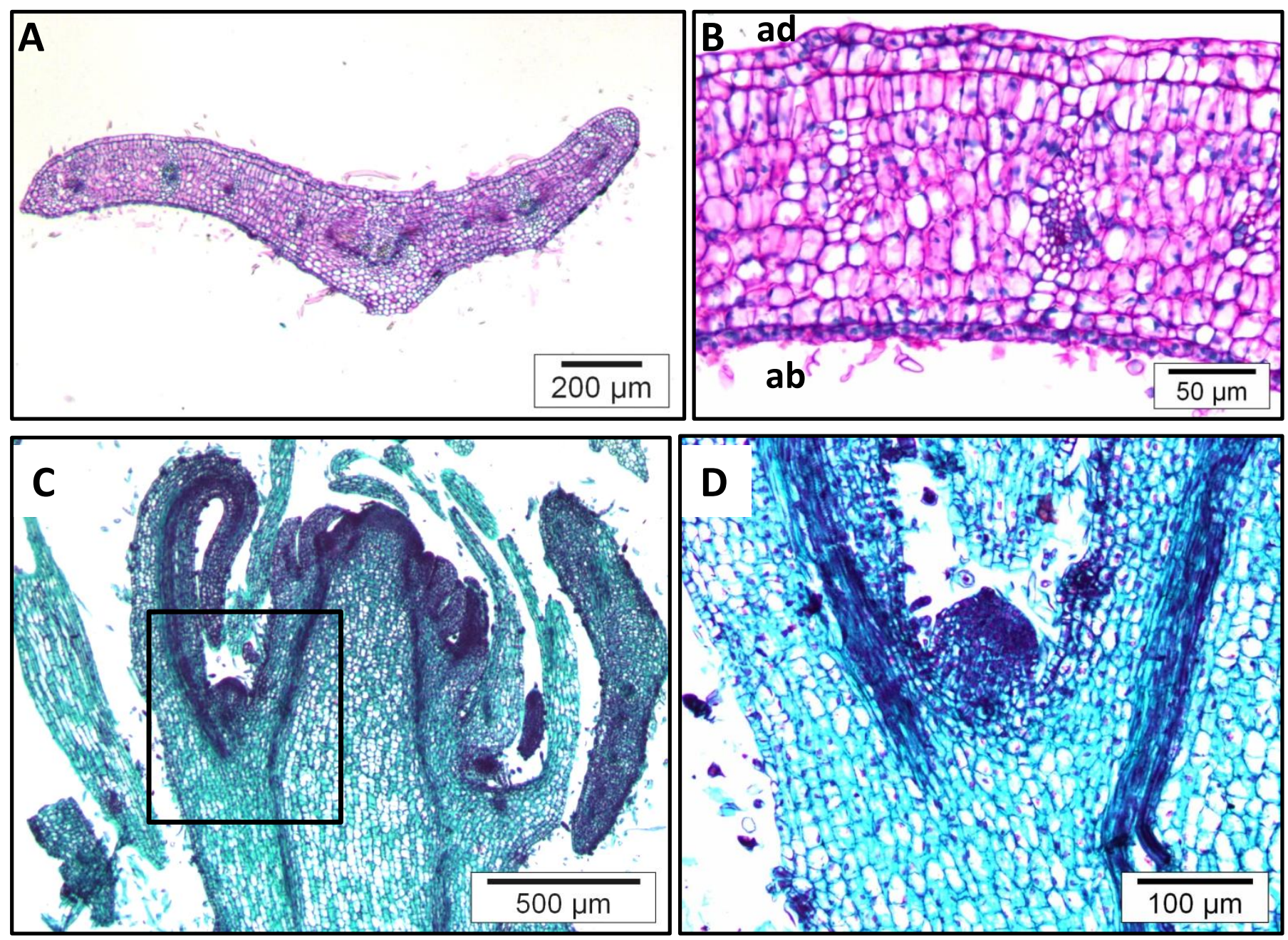

Figure 3. Histological analysis of shoot apex and leaf explants used as initial explants in somatic embryogenesis initiation of $Q$. Ilex. A Transverse section of a leaf explant prior to culture on induction medium. B Magnification of leaf blade in A. Note the differences between adaxial (ad) and abaxial (ab) sides. C Longitudinal section of a shoot apex explant prior to culture on induction medium. D Magnification of C (square) to show axillary meristem. PAS-naphthol blue-black reaction was applied in photograph A and B, whereas double-stain safranin-fast green was used in photograph C and D. 
Table 1. Callus formation and embryogenic response in leaf and shoot apex explants derived from axillary shoot cultures of a mature Quercus ilex tree, genotype Q10.

\begin{tabular}{|c|c|c|c|c|}
\hline \multirow[t]{2}{*}{$\begin{array}{l}\text { Treatment } \\
(\mu \mathrm{M})\end{array}$} & \multicolumn{2}{|c|}{$\begin{array}{l}\text { Explants forming callus } \\
\qquad(\%)^{1}\end{array}$} & \multicolumn{2}{|c|}{$\begin{array}{l}\text { Somatic embryogenesis } \\
(\%)^{2}\end{array}$} \\
\hline & Leaf & Apex & Leaf & Apex \\
\hline Control & $22.0 \pm 2.2 \mathrm{a}$ & $25.5 \pm 1.7 \mathrm{a}$ & $2 \pm 1$ & $3 \pm 1.7$ \\
\hline 5.37 NAA+2.22 BA & $72.0 \pm 2.8 b c$ & $88.0 \pm 4.0 \mathrm{~d}$ & $0 \pm 0$ & $4 \pm 1.4$ \\
\hline 10.74 NAA+2.22 BA & $79.0 \pm 1.7 \mathrm{c}$ & $90.0 \pm 3.6 \mathrm{~d}$ & $0 \pm 0$ & $5 \pm 2.2$ \\
\hline 21.44 NAA+2.22 BA & $67.0 \pm 1.8 b$ & $80.0 \pm 1.4 c$ & $3 \pm 0.9$ & $4 \pm 2.4$ \\
\hline $2.85 \mathrm{IAA}+2.22 \mathrm{BA}$ & $59.0 \pm 1.1 b$ & $77.0 \pm 1.8 \mathrm{c}$ & $0 \pm 0$ & $3 \pm 0.9$ \\
\hline $5.71 \mathrm{IAA}+2.22 \mathrm{BA}$ & $70.0 \pm 3.6 b$ & $78.0 \pm 1.0 \mathrm{c}$ & $0 \pm 0$ & $3 \pm 1.7$ \\
\hline 11.42 $\mathrm{IAA}+2.22 \mathrm{BA}$ & $64.0 \pm 2.8 b$ & $60.0 \pm 1.4 b$ & $0 \pm 0$ & $4 \pm 1.4$ \\
\hline \multirow[t]{2}{*}{$22.83 \mathrm{IAA}+2.22 \mathrm{BA}$} & $79.0 \pm 3.8 \mathrm{c}$ & $89.0 \pm 1.7 \mathrm{~d}$ & $0 \pm 0$ & $8 \pm 2.4$ \\
\hline & $\begin{array}{l}\text { F-test } \\
\text { Treatment (A) } \\
\text { Explant (B) } \\
\text { A x B }\end{array}$ & $\begin{array}{l}\mathrm{p} \leq 0.001 \\
\mathrm{p} \leq 0.001 \\
\mathrm{p} \leq 0.05\end{array}$ & $\begin{array}{l}\chi^{2} \\
\text { Treatment (A) } \\
\text { Explant (B) } \\
\text { A x B }\end{array}$ & $\begin{array}{l}\mathrm{ns} \\
\mathrm{p} \leq 0.001 \\
\mathrm{~ns}\end{array}$ \\
\hline
\end{tabular}

${ }^{1}$ Evaluated after 8 weeks of culture on induction medium. ${ }^{2}$ Evaluated at the end of the experiment. Induction medium consisting of MS medium, $500 \mathrm{mg} \mathrm{L}^{-1} \mathrm{HC}, 6 \mathrm{~g} \mathrm{~L}^{-1}$ Vitro agar, $30 \mathrm{~g} \mathrm{~L}^{-1}$ sucrose with or without PGRs (control).

Each value represents the mean \pm standard error of four replicates with 25 explants per replicate.

Influence of treatment and explant type on the percentage of explants forming callus was evaluated by twoway ANOVA. Within a column, means followed by different letters differ significantly at $P=0.05$ level. Influence of treatment and explant type on the percentage of somatic embryogenesis was evaluated by the $\chi^{2}$ test.

BA, benzyaminopurine; IAA, indole-3-acetic acid; NAA, $\alpha$-naphthalene acetic acid; ns, not significant. 
Table 2. Callus formation and embryogenic response in leaf and shoot apex explants derived from axillary shoot cultures of a mature Quercus ilex tree, genotype Q3.

\begin{tabular}{|c|c|c|c|c|}
\hline \multirow[t]{2}{*}{$\begin{array}{c}\text { Treatment } \\
(\mu \mathrm{M})\end{array}$} & \multicolumn{2}{|c|}{$\begin{array}{c}\text { Explants forming callus } \\
(\%)^{1}\end{array}$} & \multicolumn{2}{|c|}{$\begin{array}{c}\text { Somatic embryogenesis } \\
(\%)^{2}\end{array}$} \\
\hline & Leaf & Apex & Leaf & Apex \\
\hline Control & $8.4 \pm 2.4 a$ & $2.5 \pm 1.5 \mathrm{a}$ & $0 \pm 0$ & $1 \pm 0.9$ \\
\hline 10.74 NAA+2.22 BA & $70.0 \pm 1.6 \mathrm{~d}$ & $88.0 \pm 2.4 \mathrm{e}$ & $0 \pm 0$ & $10 \pm 2.2$ \\
\hline 21.44 NAA+2.22 BA & $48.0 \pm 2.5 c$ & $56.0 \pm 2.8 c$ & $1 \pm 0.9$ & $11 \pm 1.7$ \\
\hline 2.85 $\mathrm{IAA}+2.22 \mathrm{BA}$ & $48.0 \pm 3.7 \mathrm{c}$ & $44.4 \pm 3.0 \mathrm{c}$ & $0 \pm 0$ & $3 \pm 1.7$ \\
\hline $5.71 \mathrm{IAA}+2.22 \mathrm{BA}$ & $49.0 \pm 3.6 c$ & $33.0 \pm 1.1 b$ & $0 \pm 0$ & $2 \pm 1.7$ \\
\hline 11.42 $\mathrm{IAA}+2.22 \mathrm{BA}$ & $60.0 \pm 4.4 d$ & $73.0 \pm 4.6 \mathrm{~d}$ & $0 \pm 0$ & $4 \pm 1.4$ \\
\hline \multirow[t]{2}{*}{22.83 IAA+2.22 BA } & $72.0 \pm 3.9 \mathrm{~d}$ & $74.0 \pm 3.9 \mathrm{~d}$ & $0 \pm 0$ & $0 \pm 0$ \\
\hline & $\begin{array}{l}\text { F-test } \\
\text { Treatment (A) } \\
\text { Explant (B) } \\
\text { A x B }\end{array}$ & $\begin{array}{l}\mathrm{p} \leq 0.001 \\
\mathrm{~ns} \\
\mathrm{p} \leq 0.01\end{array}$ & $\begin{array}{l}\chi^{2} \\
\text { Treatment (A) } \\
\text { Explant (B) } \\
\text { A x B }\end{array}$ & $\begin{array}{l}\mathrm{p} \leq 0.01 \\
\mathrm{p} \leq 0.001 \\
\mathrm{~ns}\end{array}$ \\
\hline
\end{tabular}

${ }^{1}$ Evaluated after 8 weeks of culture on induction medium. ${ }^{2}$ Evaluated at the end of the experiment. Induction medium consisting of MS medium, $500 \mathrm{mg} \mathrm{L}^{-1} \mathrm{HC}, 6 \mathrm{~g} \mathrm{~L}^{-1}$ Vitro agar, $30 \mathrm{~g} \mathrm{~L}^{-1}$ sucrose with or without PGRs (control).

Each value represents the mean \pm standard error of four replicates with 25 explants per replicate.

Influence of treatment and explant type on the percentage of explants forming callus was evaluated by two-way ANOVA. Within a column, means followed by different letters differ significantly at $P=0.05$ level.

Influence of treatment and explant type on the percentage of somatic embryogenesis was evaluated by the $\chi 2$ test.

BA, benzyaminopurine; IAA, indole-3-acetic acid; NAA, $\alpha$-naphthalene acetic acid; ns, not significant. 
Table 3. Effect of explant type used for subculture SSE at different developmental stages for holm oak Q10 embryogenic line after 6 weeks of culture in basal proliferation medium.

Subcultured explant

${ }^{1}$ NS

Developmental stage of SSE

\begin{tabular}{cccc}
\hline${ }^{1}$ Heart- & ${ }^{1}$ Cotyledonary $\leq$ & ${ }^{1}$ Cotyledonary $>$ & Total number \\
torpedo & $5 \mathrm{~mm}$ & $5 \mathrm{~mm}$ & SSE \\
& & & \\
\end{tabular}

NS

$19.3 \pm 2.8 a$

$5.1 \pm 0.5 a$

$7.1 \pm 1.1 \mathrm{a}$

$15.0 \pm 2.4 a$

$27.1 \pm 2.9 a$

Torpedo

$3.8 \pm 1.4 b$

$1.2 \pm 0.4 b$

$0.8 \pm 0.3 b$

$8.0 \pm 0.2 b$

$10.0 \pm 0.5 b$

Early cotyledonary

$1.3 \pm 0.4 b$

$0.8 \pm 0.3 b$

$0.3 \pm 0.1 b$

$8.8 \pm 0.4 b$

$9.9 \pm 0.4 b$

\section{F-test}

$P \leq 0.001$

$P \leq 0.001$

$P \leq 0.001$

$\mathrm{P} \leq 0.05$

$\mathrm{P} \leq 0.001$

Proliferation medium consisting of SH mineral salts supplemented with $\mathrm{MS}$ vitamins, $30 \mathrm{~g} \mathrm{~L}^{-1}$ sucrose, and $6 \mathrm{~g} \mathrm{~L}^{-1}$ Vitro agar.

${ }^{1}$ Mean number of SSE at specific developmental stage produced per replicate Petri dish.

Each value represents the mean \pm standard error of six replicate Petri dishes with eight explants per dish.

Within a column, means followed by different letters differ significantly at $P=0.05$ level, according to the least significant difference (LSD) or T3 Dunnett tests.

NS, nodular embryogenic structures; SSE, secondary somatic embryos. 
Table 4. Effect of glutamine and casein hydrolysate on SSEs formation in Q10 embryogenic line after subculture for 6 weeks of NS.

Nitrogen organic source

( $\mathrm{mg} \mathrm{L}^{-1}$ )
${ }^{1}$ NS

Developmental stage of SSE

\begin{tabular}{cccc}
\hline${ }^{1}$ Heart- & ${ }^{1}$ Cotyledonary $\leq$ & ${ }^{1}$ Cotyledonary $>$ & Total number \\
torpedo & $5 \mathrm{~mm}$ & $5 \mathrm{~mm}$ &
\end{tabular}

$\begin{array}{lccccr}\text { Control }^{2} & 16.7 \pm 2.9 \mathrm{a} & 5.3 \pm 0.9 & 6.9 \pm 1.1 \mathrm{a} & 15.1 \pm 1.5 \mathrm{a} & 27.3 \pm 2.5 \mathrm{a} \\ \text { Glutamine (500) } & 6.3 \pm 1.4 \mathrm{ab} & 3.0 \pm 0.8 & 1.8 \pm 0.6 \mathrm{~b} & 3.3 \pm 0.7 \mathrm{~b} & 8.2 \pm 1.6 \mathrm{~b} \\ \text { Casein hydrolysate (500) } & 4.0 \pm 0.9 \mathrm{~b} & 2.8 \pm 0.6 & 1.3 \pm 0.4 \mathrm{~b} & 2.3 \pm 0.7 \mathrm{~b} & 6.5 \pm 1.3 \mathrm{~b}\end{array}$

$\begin{array}{llllll}\text { F-test } & P \leq 0.01 & \text { ns } & P \leq 0.05 & P \leq 0.001 & P \leq 0.001\end{array}$

Proliferation medium consisting of $\mathrm{SH}$ mineral salts supplemented with MS vitamins, $30 \mathrm{~g} \mathrm{~L}^{-1}$ sucrose, and $6 \mathrm{~g} \mathrm{~L}^{-1}$ Vitro agar.

${ }^{1}$ Mean number of SSE at specific developmental stage produced per replicate Petri dish.

${ }^{2}$ Proliferation medium without nitrogen organic.

Proliferation medium consisting of $\mathrm{SH}$ mineral salts supplemented with MS vitamins, $30 \mathrm{~g} \mathrm{~L}^{-1}$ sucrose, and $6 \mathrm{~g} \mathrm{~L}^{-1}$ Vitro agar.

Each value represents the mean \pm standard error (SE) of six replicate Petri dishes with eight explants in each dish.

Within a column, means followed by different letters differ significantly at $P=0.05$ level, according to the least significant difference (LSD) or T3 Dunnett tests.

NS, nodular embryogenic structures; SSE, secondary somatic embryos; ns, not significant. 
Table 5. Effect of cold storage pretreatment on germination response of holm oak somatic embryos from Q10 embryogenic line.

\begin{tabular}{|c|c|c|c|c|c|c|}
\hline \multirow{2}{*}{$\begin{array}{l}\text { old storage } \\
\text { (months) }\end{array}$} & \multirow{2}{*}{$\begin{array}{c}\text { Root only } \\
(\%)\end{array}$} & \multirow{2}{*}{$\begin{array}{c}\text { Shoot only } \\
(\%)\end{array}$} & \multicolumn{4}{|c|}{ Conversion (shoot+root) } \\
\hline & & & (\%) & $\mathrm{RL}(\mathrm{mm})$ & $\mathrm{SL}(\mathrm{mm})$ & LN \\
\hline 0 & $12.5 \pm 6.4$ & $0.0 \pm 0.0$ & $16.7 \pm 4.2 \mathrm{a}$ & $10.0 \pm 8.0 a$ & $5.5 \pm 1.6 a$ & $0.5 \pm 0.4 a$ \\
\hline 2 & $12.5 \pm 6.4$ & $4.2 \pm 3.3$ & $66.7 \pm 9.4 b$ & $91.3 \pm 7.7 b$ & $12.6 \pm 0.6 b$ & $3.5 \pm 0.2 b$ \\
\hline 3 & $29.2 \pm 3.3$ & $0.0 \pm 0.0$ & $12.5 \pm 0.0 a$ & $73.0 \pm 15.1 b$ & $10.3 \pm 2.1 \mathrm{ab}$ & $2.0 \pm 0.5 a$ \\
\hline F-test & ns & ns & $P \leq 0.01$ & $P \leq 0.01$ & $P \leq 0.05$ & $P \leq 0.01$ \\
\hline
\end{tabular}

Germination medium consisting of GD mineral salts and vitamins supplemented with $30 \mathrm{~g} \mathrm{~L}^{-1}$ sucrose, $6 \mathrm{~g} \mathrm{~L}^{-1}$ Vitro agar, $0.44 \mu \mathrm{M}$ BA and $20 \mu \mathrm{M}$ STS.

Each value represents the mean \pm standard error of 4 replications with 6 explants in each replicate.

Within a column means followed by different letters differ significantly at $P=0.05$ level, according to the least significant difference (LSD) test.

ns, not significant; RL, root length; SL,

shoot length; LN, leaf number. 